\title{
$O$ conceito de indivíduo em Theodor W. Adorno
}

\author{
Michel Aires de Souza Dias² \\ Recebido em maio de 2019 \\ Aceito em outubro de 2019
}

\section{RESUMO}

Quando o indivíduo se libertou do mundo medieval, não havia mais a Igreja e os códigos sociais e morais que formavam sua individualidade. Não havia mais nenhuma referência ou modelo que pudesse lhe servir de guia. O resultado disso foi a deterioração do próprio indivíduo, que se viu subjugado pelas leis impessoais do mercado. A partir desse diagnóstico, o presente artigo pretende refletir sobre a constituição do indivíduo na sociedade moderna. Em um primeiro momento, procura-se argumentar que a sociedade tem uma função fundamental na transformação do indivíduo em uma mônada, ou seja, em um ser atomizado, alienado e determinado em seu íntimo pela lei social estabelecida da exploração econômica. A partir disso, mostra-se como o indivíduo se constitui como um ser social, sendo reduzido a um corpo reificado, adestrado, que deve se adaptar aos mecanismos que regulam a produção.

Palavras-chave: Adorno; Indivíduo; Mônada; Sociedade; Corpo.

\begin{abstract}
When the individual broke free from the medieval world, there was no more the Church and the social and moral codes that formed his individuality. There was no more other reference or model that could serve as a guide. The result of this was the deterioration of the individual himself, that was subdued by the impersonal laws of the market. From this diagnosis, the present article intends to reflect on the constitution of the individual in modern society. In a first moment, one seeks to argue that society has a fundamental role in transforming the individual into a monad. In other words, in an atomized being, alienated and determined within itself by the established social law of economic exploitation. From that, shows how the individual is constituted as a social being, being reduced to a reified body, trained, that must adapt to the mechanisms that regulate production.
\end{abstract}

Keywords: Adorno; Individual; Monad; Society; Body.

$\mathrm{P}$ ara os pensadores da Escola de Frankfurt, a sociologia não se reduz e nem se dissolve em pesquisas setoriais e especializadas, como as pesquisas de mercado, típicas da sociologia americana. Ao contrário, a pesquisa social é para eles a teoria da sociedade como um todo, uma teoria posta sob o signo da categoria de totalidade e da

${ }^{1}$ O presente artigo deve constituir um dos capítulos da Tese de doutorado "Educação, formação cultural e emancipação em Adorno", que será defendido na segunda metade de 2020, na Universidade de São Paulo.

${ }^{2}$ Possui graduação em Filosofia pela Universidade Estadual Paulista (UNESP). É mestre em Filosofia pela Universidade Federal de São Carlos (UFSCAR). Atualmente faz doutorado em Educação pela Universidade de São Paulo (USP). Contato: michelaires@usp.br 
dialética, e dirigidas ao exame das relações existentes entre os âmbitos econômicos, psicológicos e culturais da sociedade contemporânea (REALE; ANTISERI, 2009). Desse ponto de vista, na concepção de Adorno (1978b), a sociologia não pode ser uma ciência isolada de outras disciplinas, uma vez que o trabalho interdisciplinar é fundamental para refletir sobre a totalidade social. Se a sociologia pretende enunciar proposições que se refiram à totalidade das relações e forças sociais, a psicologia, a história e a economia são imprescindíveis para o trabalho do sociólogo. Nesse sentido, o que há de específico na sociologia não são seus objetos, que também estão presentes em outras ciências, mas é o modo de concebê-los, isto é, a relação entre todos esses objetos e as leis da socialização.

Adorno como pensador dialético não concebe os fenômenos isoladamente, como entidades prontas, acabadas, como se existissem de forma independente. Ao contrário, todos os objetos e fenômenos analisados formam uma cadeia articulada de interdependência e condicionamento mútuo. Desse modo, na vida social nada pode ser compreendido separadamente, sem conexão com os fenômenos que o cercam. Na dialética o particular e o universal, o sujeito e o objeto, a consciência e a realidade interagem. Os objetos do mundo empírico devem ser compreendidos como objetos de um todo. Todo fenômeno é mediado pela totalidade e concretude da realidade histórica e social. É a partir dessa perspectiva que Adorno pensa o indivíduo. Este não pode ser pensado como a antítese da socialização, uma vez que ele não é um ser fixo e isolado, independente das determinações sociais. O indivíduo é, antes de tudo, um ser mediado socialmente. Desse modo, o que é essencial é a reflexão sobre a relação dialética entre indivíduo e sociedade. A partir desse pressuposto, Adorno procura compreender o indivíduo como uma mônada da totalidade social.

\section{O indivíduo como mônada}

Refletir sobre o conceito de indivíduo na obra de Adorno é relevante, justamente porque ele supera a velha dicotomia da sociologia entre indivíduo e sociedade. Algumas teorias sociais partem do postulado de que são as relações sociais entre os indivíduos que determinam as estruturas da sociedade. Outras, por sua vez, 
analisam a sociedade como algo constituído e buscam compreender como as estruturas sociais condicionam as ações dos indivíduos. Já para o pensador alemão, essas duas instâncias não podem ser pensadas isoladamente, uma vez que são interdependentes e se condicionam mutuamente: "ocorre um nexo funcional, uma interação entre os homens individuais e o todo e - isto é essencial" (ADORNO, 2008a, p.102). Desse modo, indivíduo e sociedade só podem ser pensados dialeticamente.

O conceito de indivíduo foi pouco refletido pela sociologia, sendo muito mais um objeto da filosofia. Como observa Adorno:

\begin{abstract}
O tema do indivíduo é relativamente raro na sociologia. De um modo geral, ela dedica-se ao estudo das "relações entre indivíduos", dos grupos, classes e instituições sociais, e a sua tendência é para considerar o indivíduo um dado irredutível, confiando sua análise à Biologia, à Psicologia e à Filosofia. Esta última, que também tentara a tarefa de reflexão crítica sobre o conceito, propôs durante largo tempo que o indivíduo fosse absolutizado como categoria extra-social (ADORNO, 1978b, p.45).
\end{abstract}

Desde o início da filosofia moderna, o indivíduo foi pensado como um ser acabado, fixo, como se tivesse uma essência dada a priori. No século XVII, o filósofo francês René Descartes vai ser o primeiro a colocar a pergunta “o que sou?". Sua resposta: "uma coisa que pensa”. A certeza do cogito inaugura a noção de indivíduo como um eu lógico, autônomo e fechado em si mesmo. Posteriormente, Kant concebeu a razão como a capacidade que o ser humano tem, partindo de princípios a priori, representar e conhecer o mundo. Desse modo, o indivíduo surge como um eu transcendental e como um ser autônomo moralmente. Fichte concebeu o Eu como absoluto. Husserl como uma consciência pura. Toda filosofia moderna pensou o indivíduo como um ser acabado, independente das determinações sociais. Desde o seu aparecimento, "o conceito de indivíduo quis sempre designar algo concreto, fechado e autossuficiente" (ADORNO, 1978b, p.46).

Em seu ensaio "Indivíduo", Adorno (1978b) procurou mostrar que essa concepção de indivíduo como um eu lógico é muito mais antiga, teve sua origem em Boécio. Desde aquela época esse conceito sempre designou algo fechado em si mesmo, algo que não se pode dividir, como se fosse uma unidade ou espírito. Essa visão perdurou até a época do liberalismo. Sob a influência da teoria da livre concorrência 
surgiu o costume de considerar o indivíduo como algo absoluto, um ser em si. Foi somente quando a filosofia se converteu em ciências da sociedade, no século XIX, que essa crença foi abalada, e o indivíduo apareceu como um ser socialmente mediado:

\begin{abstract}
A vida humana é, essencialmente e não por mera casualidade, convivência. Com esta afirmação, põe-se em dúvida o conceito do indivíduo como unidade social fundamental. Se o homem, na própria base de sua existência, é para os outros, que são os seus semelhantes, e unicamente por eles é o que é, então sua definição última não é de uma indivisibilidade e unicidades primárias mas, outrossim, a de uma participação e comunicação necessárias com os outros. Mesmo antes de ser indivíduo o homem é um dos semelhantes, relaciona-se com os outros antes de referir-se explicitamente ao eu; é um momento das relações em que vive, antes de poder chegar finalmente, à autodeterminação (ADORNO, 1978b, p.47).
\end{abstract}

Os estudos de Adorno (1978b) mostraram que essa ideia de convivência se expressava através do conceito de pessoa. Persona era o termo romano para a máscara do teatro clássico. Em Cícero, a palavra foi sublimada para designar a máscara ou o titular do papel, por exemplo, o filósofo, e a dignidade com que este representa esse papel, como se fosse um ator. Contudo, essa doutrina da pessoa somente adquiriu o status de individualidade como expressão social com a Reforma protestante. Esse fato se constitui para o frankfurtiano como um momento importante no desenvolvimento histórico do indivíduo. Para ele, essa noção é inovadora, uma vez que, nas circunstâncias em que vive o indivíduo, e mesmo antes de ter consciência de si, ele deve representar determinados papéis na sociedade. Em consequência desses papéis, e em relação aos seus semelhantes, o homem torna-se aquilo que ele é: filho de uma mãe, aluno de um professor, membro de uma tribo, praticante de uma profissão.

Essa imagem de pessoa humana, que representa certos papéis sociais, corrobora para Adorno (1978b) a tese da relação intrínseca e indissolúvel do indivíduo com sua sociedade. Para ele, se quiséssemos prescindir desse caráter funcional da pessoa para procurar em cada um o seu significado único e absoluto, não conseguiríamos chegar ao indivíduo puro, em sua singularidade indefinível, mas apenas a um ponto de referência sumamente abstrato, que só tem significado em relação ao contexto social. Com isso, o indivíduo só pode se constituir mediado socialmente. A própria pessoa como entidade biográfica é uma categoria social. Ela se 
constitui em sua relação vital com outras pessoas. Desse ponto de vista, Adorno (1978a) compreende a sociedade como a soma de indivíduos singulares, onde uns dependem dos outros e na qual o todo só pode subsistir em virtude da unidade das funções assumidas pelos seus membros. A cada um se atribui uma tarefa funcional; todos, por seu turno, estão condicionados, em grande parte, pela sua participação no contexto geral:

\footnotetext{
Por seu turno, o que denominamos sociedade em sentido enfático representa determinado tipo de enredamento, que em certo sentido não deixa nada de fora. Um traço essencial dessa sociedade é que seus elementos individuais são apresentados, ainda que de modo derivado e a seguir até mesmo anulado, como relativamente iguais, dotados com a mesma razão, como se fossem átomos desprovidos de qualidades, definidos propriamente apenas por meio de sua razão de autoconservação, mas não estruturados em um sentido estamental e natural (ADORNO, 2008a, p.103-4).
}

Como podemos notar, o conceito de sociedade é propriamente um conceito que designa uma relação entre indivíduos. É um conceito que não pode ser hipostasiado, uma vez que é um conceito dialético. Não há como pensar a sociedade como algo absoluto para além dos indivíduos ou independente deles. Da mesma forma, a sociedade não é uma soma ou aglomerado de indivíduos. Ela só se efetiva através dos indivíduos, mas, enquanto é relação desses indivíduos, não pode ser reduzido a eles, e, por outro lado, também não pode ser apreendido como um conceito superior existente por si próprio. O que existe é uma interação recíproca entre os indivíduos e uma objetividade que se autonomiza em relação aos mesmos (ADORNO, 2008a). Desse modo, seria difícil compreender o indivíduo como algo isolado do papel social que ele representa: "Decerto, não se pode traçar uma divisão tão simples entre as pessoas em si e seus assim chamados papéis sociais. Estes penetram profundamente nas próprias características das pessoas, em sua constituição íntima” (ADORNO, 2009, p.62).

A ideia de "máscara social" como marca do indivíduo, onde este é obrigado a exercer certos papéis sociais, tem uma importância fundamental na sua atomização e isolamento na sociedade capitalista. O indivíduo torna-se obrigado a obter uma função, cargo ou profissão na sociedade para poder sobreviver. A teoria das mônadas de Leibniz ofereceu a Adorno um modelo conceitual para a visão individualista do 
homem concreto burguês. No aforismo "Mônada", do livro Mínima moralia, ele procurou mostrar que a sociedade tem uma função fundamental na determinação do indivíduo como uma mônada isolada, desconectada de outras mônadas, exercendo certos papéis sociais e agindo conforme as leis do mercado no interesse de sua autopreservação. Como um ser atomizado, o indivíduo se torna a imagem e semelhança do mercado, refletindo a lei social da exploração econômica. Como observa Musse (2016), o predomínio do papel social na constituição da individualidade no mundo moderno confirma a teoria marxista da alienação. Na sociedade capitalista, o indivíduo surge determinado pelas relações impessoais do mercado, mas alheio a ele, sem consciência das suas determinações:

O indivíduo deve a sua cristalização às formas da economia política, em especial à organização do mercado urbano. Ainda como oponente da pressão da socialização ele permanece seu mais autêntico produto e se lhe assemelha. Aquilo que a resistência lhe permite, cada gesto de independência, é gerado no interesse monadológico e no sedimento deste como caráter. Justamente na sua individualização o indivíduo reflete a lei social estabelecida da exploração, ainda quando mediada ao extremo (ADORNO, 2008b, p.145)

Com a ideia de mônada Adorno pretendeu mostrar duas características da individualidade na sociedade administrada e no capitalismo tardio: primeiro, sua condição de "célula" isolada do contato "ativo" (pode-se dizer, consciente) com o meio social que está envolvido, bem como com as demais células que compõe este meio. Esta, em seu isolamento cego, traz em sua constituição a mediação social sob uma forma velada e, portanto, não reflexiva. Segundo, como átomo econômico individual da sociedade burguesa, a existência do indivíduo se deve ao mercado e as formas de economia política (MORAES, 2006).

A sociedade individualista burguesa, que surge no mundo moderno, não representou para Adorno a emancipação do indivíduo. Na medida em que o homem se viu liberto das instituições e dos códigos sociais e morais que o prendiam ao mundo medieval, não havia mais grupos ou entidades que poderiam servir de modelo para guiar sua vida. Desse modo, o indivíduo passou a ser responsável pela sua própria existência. Ele se viu livre, sem nenhuma referência, tornando-se um ser ativo, responsável por seus atos e por sua felicidade. Sua vida agora passou a ser pensada no 
âmbito da sociedade. Esta torna-se um campo de forças onde o indivíduo precisa lutar pela sua sobrevivência. Mas, sem nenhuma referência, substrato, ou conteúdo que pudesse lhe guiar, o homem se abandona à realidade em busca de sua autopreservação. A consequência disso foi a ruína do próprio indivíduo, que se viu subjugado pelas leis impessoais do mercado.

$\mathrm{Na}$ avaliação de Adorno (2008b), o desaparecimento do indivíduo no mercado significou a eliminação da própria individualidade e, com ela, sua resistência ao heterônomo. Para ele, a exaltação do indivíduo autossuficiente como senhor de si mesmo, que age em nome de sua autopreservação produz um individualismo anárquico e desenfreado, onde tudo é possível. Essa “emancipação” em vez de libertálo, rouba-lhe a força de ser livre, uma vez que, por mais real que possa ser o indivíduo na sua relação com os outros, concebido como absoluto, ele não passa de abstração. Ele não tem conteúdo algum que não seja socialmente constituído, nenhum impulso que transcenda a sociedade, que não seja dirigido a levar adiante a condição da sociedade. Desse modo, "cada é um modelo da gigantesca maquinaria econômica que, desde o início, não dá folga a ninguém, tanto no trabalho quanto no descanso, que tanto se assemelha ao trabalho" (ADORNO, 1985, p.105). Quando o todo se dissolve no indivíduo, este desaparece e torna-se mero objeto social:

\footnotetext{
No que tange à sociedade a condição absoluta atribuída ao indivíduo indica a passagem da mediação universal da relação social - que como troca sempre inclui um limite ao interesse que nele se realiza em cada caso - para a dominação universal, da qual se apossam os mais fortes. Ao dissolver-se toda mediação no próprio indivíduo, que lhe permitia ser até certo ponto sujeito social, ele se empobrece, se embrutece e regride à condição de mero objeto social. [...] Se hoje o remanescente do humano parece aderir unicamente ao indivíduo em declínio, então ele clama pelo fim dessa fatalidade, que individualiza os homens unicamente para, isolados, poder quebra-los tanto mais completamente (ADORNO, 2008b, p.147).
}

Apesar do indivíduo ter sido liquidado na sociedade capitalista, para Adorno (2008b) essa liquidação não pode ser imputada ao próprio indivíduo, mesmo que esse colabore para sua anulação. A crítica reacionária à cultura, que percebe a ruína da individualidade e da sociedade, procuram culpar o indivíduo por sua "superficialidade", “vacuidade mecânica” e "fraqueza neurótica” (ADORNO, 20o8b, p.145). Contudo, esses 
críticos da cultura foram incapazes de compreender o princípio social da individualização (principium individuationis). Eles não conseguiram perceber as mediações sociais que fazem do indivíduo aquilo que ele é, um ser atomizado, fragmentado e alienado da totalidade social que o determina. Nesse sentido, eles foram incapazes de perceber que é a "crua realidade material que prende o humano na desumanidade" (ADORNO, 2008b, p.146). Numa sociedade falsa, incapaz de conciliar os interesses particulares com as necessidades do universal, o processo de socialização é deformado. Ao socializar o indivíduo, a totalidade falsa o individualiza pressionandoo a ser de uma determinada forma:

\footnotetext{
Rigorosamente falando, a socialização afeta o "homem" como pretensa individualidade exclusivamente biológica, não tanto desde fora, mas, sobretudo, na medida em que envolve o indivíduo em sua própria interioridade e faz dele uma mônada da totalidade social. Nesse processo, a racionalização progressiva, como padronização do homem, faz-se acompanhar de uma regressão igualmente progressiva. $\mathrm{O}$ que outrora talvez acontecesse aos homens de fora para dentro, têm eles agora de sofrê-lo também no seu íntimo (ADORNO, 1978a, p.40-1).
}

Com o advento do capitalismo tardio, dominado pelas grandes corporações, pela globalização dos mercados, pelo consumo de massa e pela racionalidade tecnológica, a sociedade tornou-se cada vez mais administrada. A sociedade administrada se define pela convivência entre capital e instituições democráticas, visando o controle e a dominação social, calcadas na racionalidade administrativa e tecnológica, tornando os indivíduos em objetos de organização e planejamento, objetivando a manutenção do sistema capitalista. Nessa forma de sociedade, a racionalidade técnica foi capaz de estabelecer padrões, formas de comportamento e atitudes que predispõe os indivíduos a aceitarem e introjetarem seus mandamentos. Desse modo, a socialização se tornou total.

Em seus estudos sobre o indivíduo na sociedade administrada, Adorno não o concebeu apenas ligado à categoria de classe social. O capitalismo atingiu uma tal amplitude no século XX, que o conceito de classe ao qual estava ligado o indivíduo se tornou mais fluido. Pertencer a uma classe significava estar ligado a um certo status social, a um certo ethos e a certas relações de solidariedade. Contudo, hoje, "a 
modernidade capitalista não se dá mais a conhecer através de classes sociais e suas formas de organização, solidariedade, ethos e valores, mas encontra-se a margem da lei, como se constata nas práticas dos grupos, cliques ou gangues - os rackets" (MATOS, 2008, p.149). Quando o indivíduo participa de um grupo ou organização, ele se simpatiza com outros que possuem o mesmo modo de ser das entidades que a compõe. Nesse sentido, pertencer a uma igreja evangélica ou ao exército significa possuir o mesmo modo de ser das pessoas que o formam. Nesses grupos a figura dos rackets assume papel fundamental como um ser atomizado, isolado e alienado das forças que o subjugam. Os rackets que dominam a sociedades são os exemplos mais acabados de mônadas sociais. Eles se constituem como especialistas, managers de todo tipo, dirigente de sindicatos, políticos, engenheiros altamente qualificados, advogados, líderes empresariais e todo tipo de predador individualista que busca defender seus interesses dentro de grupos ou organizações. Adorno descreveu a figura dos rackets como a forma mais acabada de mônada social em uma passagem de Minima moralia. Segundo ele:

\begin{abstract}
Se, como ensina uma teoria contemporânea, a sociedade é uma sociedade de rackets, então o seu modelo mais fiel é justamente o contrário do coletivo, a saber, o indivíduo como mônada. $\mathrm{Na}$ prossecução dos interesses absolutamente particulares de cada indivíduo é onde se pode estudar com maior precisão a essência do coletivo na sociedade falsa; e pouco falta para que, desde o princípio, se deva conceber a organização dos impulsos divergentes sob o primado do eu ajustado à realidade como uma íntima quadrilha de bandidos com chefe, séquito, cerimonial, juramentos, traições, conflitos de interesses, intrigas e tudo o mais (ADORNO, 2001, p.35).
\end{abstract}

Os rackets, como mônadas isoladas, refletem a imagem do mercado como rapinagem e exploração. São indivíduos que mimetizam a realidade e se ajustam a ela de tal forma que suas atitudes e emoções são sempre violentas. Eles agem de forma enérgica em busca de seus interesses. Desse modo, eles são parecidos como líderes de quadrilha que se envolvem sempre em intrigas e conflitos de interesses: "Basta observar certas emoções em que o indivíduo se afirma energicamente contra o ambiente, como a raiva. O raivoso sempre se apresenta como líder de bando de si próprio" (ADORNO, 2008b, p.41). Como sujeito agressivo de si mesmo, que se adapta ao ambiente opressivo de seu meio, ele personifica o princípio opressor da sociedade. 
Com isso, aquilo que parece representar o mais individual, na verdade representa o mais geral (ADORNO, 20o8b).

Em uma época de capitalismo flexível e neoliberalismo, o conceito de rackets torna-se imprescindível para pensar o mundo atual, uma vez que o indivíduo está cada vez mais atomizado e fragmentado. Na sociedade neoliberal, a busca desenfreada pelo dinheiro, a competição, o consumo compulsivo, a busca de reconhecimento simbólico, a labuta do dia-a-dia não permitem ao homem determinar sua própria vida como projeto, como determinação consciente. A sociedade se torna cada vez mais individualista na medida em que valoriza o desempenho, o esforço pessoal, o sacrifício e a adaptação. Em contrapartida, a radicalização política, os discursos de ódio, a intolerância, o autoritarismo, a xenofobia, o racismo, os conflitos étnicos, o surgimento de líderes fascistas e de milícias são indícios de que os rackets têm dominado a sociedade. Hoje, a vida social enclausura o indivíduo de tal forma que ele não se distingue de seu meio. Como afirma Erich Fromm nessa passagem:

O indivíduo deixa de ser ele mesmo; adota inteiramente o tipo de personalidade que lhe é oferecido pelos padrões culturais; e, portanto, tornase exatamente igual a todos os outros e ao que os outros esperam que ele seja [...] Eles parecem tão semelhantes ao seu entorno que só podem ser distinguidos dele com grande dificuldade. (FROMM, 1960, Apud GIDDENS, 2002, p.176)

A ideia de um indivíduo singular, como mônada isolada, liberto das amarras do antigo regime surgiu no século XVIII. A expansão do capitalismo nesta época possibilitou a tomada de consciência da classe burguesa. A revolução industrial, o avanço da técnica e das ciências possibilitaram ao homem uma forte crença no poder da razão como critério de todo julgamento. Com isso, foi somente naquela época que o homem se tornou senhor de si mesmo, como um indivíduo autoconsciente:

O indivíduo surge, de certo modo, quando estabelece o seu eu e eleva o seu ser para si, a sua unicidade, à categoria de verdadeira determinação. Antes, a linguagem filosófica e a linguagem comum indicavam tudo isso mediante a palavra "autoconsciência". Só é indivíduo aquele que diferencia a si mesmo dos interesses e pontos de vistas dos outros, faz-se substância de si mesmo, estabelece como norma a autopreservação. E não é mero acidente fortuito que só por volta do século XVIII a palavra "indivíduo" tenha passado a designar o homem singular, e que a própria coisa não seja muito mais antiga do que a 
palavra, dado que só começou a existir nos alvores do Renascimento (ADORNO, 1978b, p.52).

Como avalia Adorno (1978b), o indivíduo não existe separado da sociedade. Essa autoconsciência da singularidade do eu somente pode designar o indivíduo como autoconsciência social. A própria ideia de autoconsciência já supera a ideias de sujeito fechado em si mesmo, como um ser abstrato. Ela somente pode surgir como uma relação, não como uma relação do indivíduo consigo mesmo, mas como uma relação com outra autoconsciência. A autoconsciência da singularidade do eu surge mediada socialmente. Ela é autoconsciência social e só se realiza a partir da interação e da socialização dos indivíduos. É na relação que os indivíduos estabelecem entre si que surge o universal: "a sociedade como unidade de mônadas, só se manifesta na medida em que o eu somos nós e nós o eu" (ADORNO, 1978b, p.52). Em consequência disso, para Adorno, a ideia de indivíduo como um ser fixo, estável e determinado a priori é apenas uma crença, uma ficção:

\begin{abstract}
Com efeito, a crença na independência radical do ser individual em relação ao todo nada mais é, por sua vez, do que uma aparência. A própria forma do indivíduo é a forma de uma sociedade que se mantém viva em virtude da mediação do mercado livre, no qual se encontram sujeitos econômicos livres e independentes. Quanto mais o indivíduo é reforçado, mais cresce a força da sociedade, graças a relação da troca em que o indivíduo se forma. Ambos os conceitos são recíprocos. O indivíduo, num sentido amplo, é o contrário do ser natural, um ser que, certamente, se emancipa e se afasta das simples relações naturais, que está desde o princípio referido à sociedade, de um modo específico, que, por isso mesmo, recolhe-se em seu próprio ser (ADORNO, 1978b, p.53).
\end{abstract}

Como podemos notar nesta passagem, o próprio indivíduo como ser biológico perde suas características naturais e passa a ser moldado socialmente. $\mathrm{O}$ conceito de individuação biológica para Adorno (1978b) é tão abstrato e indeterminado que não pode expressar o que realmente o indivíduo é. Ele significa algo mais do que apenas o seu ser biológico. A própria existência natural e biológica do ser humano já está mediatizada pelo gênero humano. Desse modo, não é possível um conhecimento do indivíduo se ele não for pensado do ponto de vista das determinações sociais e, portanto, do ponto de vista do seu ser social. Adorno parte aqui da própria concepção de constituição do indivíduo em Marx. 


\section{O trabalho social e o corpo reificado}

No final do século XIX, Marx já havia feito a crítica ao conceito de indivíduo iluminista como um eu lógico, acabado, estável, com uma essência fixa, biologicamente determinada. Na concepção do materialismo-histórico, o indivíduo surge determinado por aquilo que ele faz. Ele se torna o que é pelo seu ser social: "A forma como os indivíduos manifestam a sua vida, reflete muito exatamente aquilo que são. O que são coincide, portanto, com a sua produção, isto é, tanto com aquilo que produzem como a forma como produzem" (MARX; ENGELS 1976, p.19). Desse modo, é o comportamento material do homem que fomenta suas representações e pensamentos. Se examinarmos a maneira pelas quais os homens produzem os bens necessários à vida, é possível compreender as formas de seu pensamento, tais como sua moral, religião e filosofia. Nesse sentido, o pensamento torna-se o reflexo do desenvolvimento material objetivo da história (MARX; ENGELS, 1976).

A partir da influência de Marx, Adorno procura mostrar em seus ensaios que o indivíduo não possui nenhum substrato ou conteúdo que pudesse defini-lo, pois ele só se constitui por meio da sociedade, que o torna mera força de trabalho. Como Marx (2016) já havia sustentado em o Capital, com a universalização da forma mercantil, o trabalho como produtor de valor de uso, que visa a produção de objetos úteis ao bemestar dos indivíduos, é substituído pelo trabalho como produtor do valor de troca, que busca o acúmulo de capital expandindo a riqueza do capitalista. Em toda história da civilização o fim último do trabalho humano era a produção do valor de uso. O objeto produzido deveria ter uma utilidade. $O$ que se buscava era a satisfação de uma necessidade, seja ela física ou psicológica. Contudo, no modo de produção capitalista, o valor de troca passa a ser mais importante que o valor de uso, pois ele é imprescindível para a reprodução do capital. A substituição do valor de uso pelo valor de troca, como critério de intercâmbio material entre os homens, lançou as bases para a exploração do trabalho humano e, consequentemente, para a expansão do capital. A partir daí o homem foi reduzido à mera força de trabalho, perdendo toda sua autonomia e tornando-se um apêndice da máquina. 
O que é característico nas sociedades capitalistas é a transformação de todas as coisas em mercadoria. Tudo o que existe passa a ter um valor. A força de trabalho não foge a essa regra. Ela é uma mercadoria como outra qualquer. Ela também possui um valor de troca. Esse valor é determinado pelo tempo de trabalho socialmente necessário de produção dos meios de subsistência do trabalhador e de sua família. Como o trabalhador só dispõe de sua força de trabalho, ele a vende ao capitalista. Assim começa o ciclo de exploração e reprodução do capital. Como o próprio Adorno avalia:

É só quando o processo que tem início com a transformação da força de trabalho em mercadoria impregna integralmente os homens e torna cada gesto deles comensurável de antemão, enquanto no mesmo passo o converte em objeto na condição de modalidade da relação de troca, que se faz possível a reprodução da vida sob as relações de produção dominantes. Sua organização integral exige a união de mortos. A vontade de viver vê-se remediada à negação da vontade de viver: a autopreservação anula a vida na subjetividade (ADORNO, 2008b, p.226-7).

Como mostra essa passagem, em vez do indivíduo realizar todas as suas potencialidades por meio do trabalho, ocorre justamente o contrário, ele perde sua humanidade, uma vez que o trabalho surge como espoliação. A subsunção formal do trabalho ao capital se efetiva a partir do momento em que o produto do trabalho se torna algo exterior ao indivíduo, torna-se algo estranho, deixa de pertencer ao seu ser. Ao vender sua força de trabalho, o operário desgasta sua atividade física e mental, mortificando seu corpo e arruinando seu espírito numa atividade que ele não se reconhece. Desse modo, ele nega-se a si mesmo e torna-se apenas uma peça dentro de uma engrenagem. Ele torna-se um ser alienado de seu trabalho e de sua própria vida. Como observou o sociólogo inglês John Horton:

A atividade social e humana do homem é o seu trabalho; os produtos do trabalho, incluindo a sociedade, são extensões da própria natureza humana. Portanto, o homem é a sua atividade, é seus objetos, o homem é a sociedade. Qualquer reificação dos objetos humanos, qualquer transcendência do produto dos homens sobre eles mesmos que os impeça de visualizar seus interesses, sua habilidade e seu poder ali expressados e afirmados, vem a ser uma evidência da alienação do homem de sua própria atividade, de seus objetos e de si mesmo (HORTON, 2008, p.82). 
No processo de alienação o indivíduo perde sua própria identidade. Ele deixa de ser um sujeito livre e autônomo, capaz de decidir e escolher seus próprios meios de vida. É como se uma parte de seu ser lhe fosse arrancada. Esse fenômeno foi analisado pela historiadora Maria Bresciani (1984), que procurou compreender essa nova sensibilidade experimentada pelo trabalhador quando ele se tornou um assalariado. Segundo ela, a primeira perda que o trabalhador experimentou foi a perda da "representação do tempo". Ele deixou de se relacionar com o tempo de modo natural, onde sua vida era regida pelos ciclos da natureza. O tempo tornou-se abstrato e linear, tornou-se tempo de trabalho, que subjuga o movimento, o ritmo e a atividade humana. A segunda perda foi o da unidade do homem com suas condições de produção. $\mathrm{O}$ trabalhador é reduzido à mera força de trabalho, sendo despojado dos seus instrumentos de trabalho. As ferramentas se autonomizam e se materializam nas máquinas, tornando dispensável o labor de suas mãos. Desse modo, o trabalhador deixou de se reconhecer na sua atividade. A terceira perda foi a das "relações pessoais", que foram substituídas pelas relações impessoais do mercado. Aquela relação de compartilhamento de experiências e aprendizagem entre o aprendiz e o mestre-artesão deixou de existir. No modo de produção capitalista, a relação entre patrão e operário torna-se mercantil. A última perda foi o do "habitat tradicional", o trabalhador fabril e urbano foi arrancado de sua vida cotidiana, ao qual ele se identificava e convivia com seus pares. Em seu vilarejo ele compartilhava experiências e construía relações sólidas. Mas, ao abandonar sua vida tradicional, ele foi impelido a levar uma vida agressiva nas cidades, sem garantias de sobrevivência. Foi a partir dessas quatro perdas que o homem deixou de ser livre e autônomo. Ele perdeu a capacidade de autodeterminação.

Ao ser reduzido a mera força de trabalho, ao ser desenraizado de sua vida e de seus afazeres, o trabalhador perde todas as referências que tinha até então. Antes, ele produzia livremente, se reconhecendo e podendo ser reconhecido em sua atividade, mas ao ser afastado das suas condições de produção, ele se aliena de sua vida e de seu trabalho. Ao vender sua força de trabalho para um patrão, e ao submeter-se a um trabalho repetitivo e mecânico, o trabalhador torna-se um objeto, uma simples mercadoria. Ele é dessubjetivado, deixa de ser um sujeito. Nesse sentido, como bem avaliou Lukács (2003), a separação do produtor dos seus meios de produção, a 
dissolução e a desagregação de todas as unidades originais de produção, são as condições econômicas e sociais do nascimento do capitalismo moderno. Todas essas condições agem no sentido de substituir por relações racionalmente reificadas as relações originais em que eram mais transparentes as relações humanas.

Lukács (2003) observou que a única atitude que restou ao trabalhador em relação a opressão do aparato produtivo foi a contemplação. No modo de produção capitalista o homem é confrontado com sua própria atividade, com seu próprio trabalho como algo objetivo, independente dele e que o domina por leis próprias, que lhe são estranhas. E isso ocorre tanto sob o aspecto objetivo quanto o subjetivo. $\mathrm{O}$ homem deixa de ser portador do processo de trabalho, com isso, ele é incorporado como parte mecanizada num sistema mecânico que já se encontra funcionando de modo totalmente independente dele. Como o processo de trabalho é cada vez mais racionalizado e mecanizado, a atitude do trabalhador perde cada vez mais seu caráter ativo para tornar-se uma atitude contemplativa.

Em um mundo cada vez mais socializado, a impotência do indivíduo só lhe permite contemplar as forças que o subjugam. A lógica do capital nivelou a tudo e a todos aos imperativos da economia. Nada escapa à mão invisível do mercado, que modela não somente os bens e serviços, mas também a alma humana. O indivíduo como mônada perde todas as suas qualidades, tornando-se igual a todos os outros. A opressão do todo se impõe como uma força devastadora, impedindo o de realizar sua plena individualidade. Ele torna-se um corpo-máquina inserido na maquinaria da produção: "Sob o a priori do vendável o vivente enquanto tal se fez ele próprio coisa, equipamento" (ADORNO, 20o8b, p.227).

Na sociedade capitalista, quem não se comporta segundo as regras econômicas tem sua vida arruinada, pode sucumbir a marginalização. Torna-se visível o caminho para o associal, para o criminoso: a recusa de colaborar torna suspeito e expõe à vingança social: O medo [Angst] de ser excluído, a sanção social do comportamento econômico, internalizou-se há muito através de outros tabus, sedimentando-se no indivíduo. Tal medo transformou-se historicamente em segunda natureza. O superego, a instância da consciência moral, não apenas coloca perante os olhos do indivíduo o que é proscrito socialmente como o mal em si, mas também mescla irracionalmente o 
medo arcaico de aniquilação física com o medo muito posterior de não mais pertencer ao conjunto social, que abarca os seres humanos em vez da natureza (ADORNO, 2015a).

Como mônada da totalidade social, desprovido de entendimento e dessubjetivado, o indivíduo se torna apenas um corpo que experimenta um mundo que o enclausura e o disciplina aos padrões de comportamento socialmente estabelecidos. O corpo é adestrado e se adapta aos mecanismos que regulam a produção: "Quanto mais complicado e mais refinada a aparelhagem social, econômica e científica, para cujo manejo o corpo já há muito foi ajustado pelo sistema de produção, tanto mais empobrecidas as vivências de que ele é capaz" (ADORNO; HORKHEIMER, 1985, p.41)3.

A história do corpo como uma das faces da subjetividade foi tratada por Adorno e Horkheimer na Dialética do Esclarecimento, no ensaio: "O interesse pelo corpo". Nesse ensaio, eles nos mostram que por trás da história conhecida da Europa ocorre uma outra, que age no sentido de transformar o corpo vivo em algo morto. É a história do destino dos instintos e das paixões humanas recalcadas e desfiguradas pela civilização.

A Dialética do esclarecimento, escrito nos anos 40, surge como uma ruptura com concepção de história do marxismo ortodoxo. Adorno e Horkheimer não partiam mais da ideia de luta de classes como o motor da história. A análise não deveria focar apenas os fundamentos econômicos da sociedade. Agora, o conflito era analisado a partir da luta entre o indivíduo e a natureza, tanto da natureza externa como da natureza interna no homem. Nesse sentido, a dominação do corpo na história da civilização aparece como a expressão desse conflito. A dominação que o homem exerceu sobre a natureza, é a mesma dominação que hoje ele exerce sobre seu próprio corpo. O mesmo processo de subjugar, dominar e transformar tudo o que é vivo em coisa também se aplica à história do corpo humano. $\mathrm{O}$ corpo e os instintos humanos sempre foram objetos de coerção no interior das práticas sociais. Essa dominação é parte de um longo processo de reificação da existência humana pela sociedade. A

3 O livro Dialética do Esclarecimento e algumas de suas notas e esboços, como "Fragmentos de uma teoria do criminoso", "Interesse pelo corpo", “o homem e o animal”, antecipa em algumas décadas os estudos de Michel Foucault sobre as práticas disciplinares e as relações de poder sobre o corpo, tal como aparecem em obras como Vigiar e Punir, História da loucura e Microfísica do poder. 
repressão e subjugação do homem teve como consequência a liberação dos impulsos destrutivos contra a civilização. Foi a partir dessa perspectiva que Adorno e Horkheimer pensaram todos os genocídios, holocausto e barbárie no decorrer do século XX.

A dominação do corpo pela sociedade teve sua origem nos primórdios da divisão social do trabalho. Com essa divisão, o prazer tornou-se o bem supremo de alguns e o trabalho a desgraça de muitos: "Quanto menos os senhores podiam dispensar o trabalho dos outros, mais desprezível ele se tornava a seus olhos. Assim como o escravo, o trabalho também foi estigmatizado" (ADORNO; HORKHEIMER, 1985, p.190). Com a divisão social do trabalho, a atividade física foi separada da atividade intelectual, ou seja, aqueles que mandam e desfrutam se diferenciam daqueles que trabalham e obedecem. Mas, esse processo foi lento, o trabalho, primeiramente, foi imposto ao escravo na antiguidade, tornando-o uma coisa, um objeto que servia ao seu senhor: "O destino dos escravos da antiguidade foi o destino de todas as vítimas até os modernos povos colonizados" (ADORNO; HORKHEIMER, 1985, p.191). A história humana é a história de sua escravidão, seja pelo poder do homem ou das instituições. Já desde o velho testamento o trabalho era visto como uma maldição, uma condenação.

Foi somente com o cristianismo que o trabalho foi louvado, anunciando a ordem burguesa. Contudo, o corpo foi amaldiçoado como a fonte de todo o mal. Ele foi visto como algo que devia ser desprezado, subjugado, como uma coisa, um objeto pecaminoso. Já na época do Renascimento, com Lutero e Calvino, o trabalho surge ligado a salvação da alma. O protestantismo dá um novo rumo ao cristianismo. $\mathrm{O}$ homem não é mais um ser passivo, submetendo-se aos preceitos e dogmas religiosos, esperando receber a graça divina. Ele agora é um ser ativo que busca no trabalho glorificar Deus e reconhece a riqueza e a felicidade humana nessa atividade. Nesse momento, o corpo já surge subjugado pelo trabalho, transformado em instrumento de produção: "Para Lutero e Calvino, o laço que ligava o trabalho à salvação já era tão complexo que a exortação febril ao trabalho, típica da reforma, quase parece um escárnio, como uma bota pisando um verme” (ADORNO; HORKHEIMER, 1985, p.191). 
Através da divisão social do trabalho, a história da civilização ocidental aparece como a história da divisão entre indivíduos superiores e inferiores. Essa divisão aparece também na religião como a separação entre corpo e alma: "O corpo explorado devia representar para os inferiores o que é mau e o espírito, para o qual os outros tinham o ócio necessário, deveria representar o sumo bem" (ADORNO; HORKHEIMER, 1985, p.191). A libertação do indivíduo das forças da natureza significou no mundo moderno uma transformação geral da cultura europeia, uma vez que diminuía a coerção externa sobre ele. Mas, em compensação, aprofundava cada vez mais a divisão social do trabalho, onde uns exerciam atividades intelectuais, usufruindo dos bens culturais; e outros exerciam atividades físicas, sendo explorados.

A hierarquia entre trabalho físico e o intelectual tornou-se a base de toda a hierarquia na civilização ocidental. Aqueles que foram obrigados a transformar o seu corpo em um instrumento de trabalho e se dedicaram à atividade física, foram humilhados e hostilizados como seres inferiores. Seu destino foi trabalhar e postergar o prazer indefinidamente, além de serem excluídos da cultura do espírito. Para eles não sobrava tempo para se dedicarem ao conhecimento e a cultura. Já aqueles que cultivaram as atividades do espírito, desempenharam o trabalho intelectual na sociedade, exercendo o papel de comando e dominação das classes inferiores. Eles se tornaram a classe que desfrutava da riqueza produzida, além de propagarem a ideologia do amor-ódio pelo corpo, cantando o louvor pelo trabalho e exaltando os valores da alma e a pecaminosidade do corpo. Essa mentalidade das massas de amoródio pelo corpo foi propagada por toda Europa:

O amor-ódio pelo corpo impregna toda a cultura moderna. O corpo se vê de
novo escarnecido e repelido como algo inferior e escravizado, e, ao mesmo
tempo, desejado como o proibido, reificado e alienado. É só a cultura que
conhece o corpo como coisa que se pode possuir; foi só nela que ele se
distinguiu do espírito, quintessência do poder e do comando, como objeto,
coisa morta, "corpus". Com o autorrebaixamento do homem ao corpus, a
natureza se vinga do fato de que o homem a rebaixou a um objeto de
dominação, de matéria bruta (ADORNO; HORKHEIMER, 1985, p.191).

As grandes produções culturais do mundo moderno somente puderam acontecer por causa dessa divisão, onde uns vivem do trabalho e outros se dedicam a 
cultura do espírito. O controle e dominação sobre o corpo significou as grandes descobertas e produções no campo da ciência, da filosofia e das artes a partir do Renascimento. Enquanto a classe burguesa se dedicava ao cultivo de si mesmo e de suas habilidades intelectuais, que permitiram a ela criar uma nova ordem mundial, ao trabalhador cabia a escravidão no interior da fábrica para produzir a riqueza da sociedade na esperança de um dia salvar sua alma dos pecados da vida terrena. Desse modo, como observou Benjamim (1994) em seu clássico texto "Sobre o conceito de história", todos os que até hoje venceram participam do cortejo triunfal, em que os dominadores espezinham os corpos dos que estão prostrados no chão. Os despojos são carregados no cortejo denominados de bens culturais. Com isso, "nunca houve um monumento de cultura que também não fosse um monumento da barbárie” (BENJAMIN, 1994, p.225).

Para Adorno e Horkheimer (1985), em uma época onde o corpo torna-se um objeto de repressão e subjugação, não é possível mais reconverter o corpo físico [Körper] em corpo vivo [Leib]. O que eles denominam de corpo físico é o corpo subjugado historicamente, reificado e transformado em instrumento de produção; ao contrário do corpo vivo, como algo orgânico, natural, biológico. O corpo físico por mais exercitado que seja, permanece um cadáver, algo morto, um objeto que foi transformado em partes da engrenagem social. O corpo é parte desse "processo perene que transformava a natureza em matéria e material. As obras da civilização são o produto da sublimação, desse amor-ódio adquirido pelo corpo e pela terra, dos quais a dominação arrancou todos os homens” (ADORNO; HORKHEIMER, 1985, p.193).

Do homem grego até os senhores feudais, a relação com o corpo foi determinada pela habilidade e destreza pessoal, mas essas características se ligavam diretamente à dominação. O cuidado com o corpo tinha uma finalidade social. $\mathrm{O}$ objetivo era a preservação do poder pessoal e a dominação pela espada. Nesse período, as relações entre os indivíduos eram ainda entre o superior e o inferior. Mas, com a entrada do mundo capitalista, a dominação deixou de ser entre indivíduos e passou a ser mediatizada pelo comércio e pelas comunicações e, sobretudo, quando surge a indústria, há uma mudança formal nas relações hierárquicas: “A humanidade deixa-se 
escravizar, não mais pela espada, mas pela gigantesca aparelhagem que acaba, é verdade, por forjar de novo a espada" (ADORNO; HORKHEIMER, 1985, p.192).

O advento do fascismo na Europa é o testemunho dessa aparelhagem técnica que domina o corpo, desfigurando os instintos e as paixões humanas. A tentativa de reconciliar a unidade perdida entre alma e corpo no fascismo, mostra a aparência socialmente necessária de uma identidade perdida. Em suas propagandas, onde se mostra o amor pela natureza e pelo destino, se expressa "uma superficial formação reativa a essa servidão ao corpo" (ADORNO; HORKHEIMER, 1985, p. 193). Quando não se pode se livrar do corpo, quando não se pode golpeá-lo, louva-o. O culto ao corpo, belo, saudável, com cartazes de drágeas de vitaminas e de cremes para a pele são apenas uma falsa aparência para reforçar a subjugação do corpo e o poderio do "novo, grande, belo e nobre tipo humano, vale dizer, dos chefes fascistas e suas tropas" (ADORNO; HORKHEIMER, 1985, p.192). Esses assassinos executam seus prisioneiros não com base em sua força superior, mas porque esse aparelho gigantesco e seus verdadeiros potentados, que continuam a não fazê-lo com as próprias mãos, entregamlhes as vítimas da razão do Estado nos porões dos quartéis generais (ADORNO; HORKHEIMER, 1985).

Para Adorno todos esses homicidas fascistas a serviço do poder ou dos poderosos são os vingadores da reificação e da impotência, são indivíduos incapazes de afirmar o seu eu no mundo. Eles possuem uma vida atrofiada, incapaz de realização, são produtos de um mundo que transformou o corpo em matéria e objeto a serviço das estruturas sociais do poder vigente. $\mathrm{O}$ ódio antissemita demonstrou isso:

O comportamento antissemita é desencadeado em situaçães em que os
indivíduos obcecados e privados de sua subjetividade se veem soltos enquanto
sujeitos. [...] O antissemitismo é um esquema profundamente arraigado, um
ritual da civilização, e os progroms são os verdadeiros assassinatos rituais.
Neles fica demonstrado a impotência daquilo que poderia refreá-los, a
impotência da reflexão, da significação e, por fim, da verdade. O passatempo
pueril do homicídio é uma confirmação da vida estúpida a que as pessoas se
conformam (ADORNO, 1985, p. 141-2).

Esses algozes do poder, que tornam a terra um inferno para os homens, representam a imagem do rancor e do ódio contra a realidade: "Eles profanam tudo o 
que tocam, aniquilam tudo o que veem à luz, e esse aniquilamento é o rancor pela reificação, eles repetem numa fúria cega sobre o objeto vivo tudo o que não podem mais fazer desacontecer" (ADORNO; HORKHEIMER, 1985, p.193). Desse modo, o antissemitismo é a prova de que o indivíduo foi dessubjetivado e se dissolveu no mundo moderno.

\section{Considerações finais}

No desenvolvimento histórico da civilização, o homem durante séculos subjugou a natureza através da técnica e esse domínio se estendeu a própria dominação humana. $\mathrm{O}$ triunfo da grande indústria no mundo moderno representou o triunfo de uma realidade que se confronta com os indivíduos como algo absoluto e esmagador. O resultado disso foi a transformação dos indivíduos em mônadas, em seres isolados, impotentes e enfraquecidos pelas condições sociais da totalidade social reificada. Todo indivíduo, sem exceção, é sujeitado como parte da maquinaria social, sendo impedido de desenvolver sua individualidade. Esse caráter repressivo da existência, que transforma o corpo em um instrumento de produção, gera um grande mal-estar, que tem como resultado a violência contra o mundo civilizado. Esse rebaixamento do corpo a uma mercadoria, que o torna matéria bruta, como um mero apêndice da máquina, significou para Adorno o retorno da barbárie primitiva, uma vez que a natureza ao se vingar, produziu uma compulsão à crueldade, que se estendeu por toda cultura ocidental: "A compulsão à crueldade e à destruição tem origem no recalcamento orgânico" (ADORNO; HORKHEIMER, 1985, p.191). Desse ponto de vista, o advento dos regimes totalitários na Europa é uma consequência da revolta da natureza. "Em certo sentido era a vingança da natureza pela crueldade e exploração que o homem ocidental lhe impusera durante gerações" (JAY, 2008, p. 321).

Hoje, vivemos uma época de xenofobia, de racismo, de misoginia e de ódio às minorias, onde líderes autoritários de extrema direita, com discursos de ódio e intolerância, têm chegado ao poder em todo o mundo. Na Turquia vimos a subida ao poder de Recip Erdogan; na Hungria, Viktor Orbán; nos Estados Unidos, Donald Trump; no Brasil. Jair Bolsonaro. Todos eles com um discurso conservador, xenófobo, 
que despreza a democracia, os direitos humanos e atacam as minorias. Essa nova regressão e recaída na barbárie surge como consequência dessa totalidade reificada, que se impõe em todas as esferas da vida social, impedindo os indivíduos de realizarem sua plena autonomia e liberdade. Em um mundo onde a socialização se tornou total, as pessoas passam a ser determinados cada vez mais por instâncias heterônomas. $O$ resultado disso são sujeitos enfraquecidos e frustrados, que buscam na dimensão do poder uma forma de compensar sua fraqueza. É essa "fraqueza do eu" que os levam a aderirem facilmente aos grandes coletivos e aos líderes autoritários com seus discursos contrários aos direitos humanos. Para Adorno, a exigência que Auschwitz não se repita é a condição primeira de toda educação em nossa época. Assim, ele propõe a reconstrução da individualidade do sujeito por meio do processo educativo, para que essa individualidade seja fonte impulsionadora de resistência. Mas esse assunto deve ficar para um próximo artigo.

\section{Referências}

ADORNO, Theodor W. 2015a. Sobre a relação entre sociologia e psicologia. In: ADORNO, Theodor W. Ensaios sobre psicologia social e psicanálise. São Paulo: Editora Unesp. p. 71-135.

ADORNO, Theodor W. 2015b. Teoria freudiana e o padrão da propaganda fascista. In: ADORNO, Theodor W. Ensaios sobre psicologia social e psicanálise. São Paulo: Editora Unesp. p. 153-189.

ADORNO, Theodor W. 2009. Tempo livre. In: ADORNO, Theodor W. Indústria cultural e sociedade. São Paulo: Paz e Terra. p. 62-70.

ADORNO, Theodor W. Introdução à sociologia. São Paulo: Editora UNESP, 2008a.

ADORNO, Theodor W. Minima moralia: reflexões da vida lesada. Rio de Janeiro: Beco do Azougue, 2008b.

ADORNO, Theodor W. Minima moralia. Lisboa: Edições 70, 2001.

ADORNO, Theodor W. e HORKHEIMER, Max. Dialética do Esclarecimento. Rio de Janeiro: Jorge Zahar, 1985.

ADORNO, Theodor W. e HORKHEIMER, Max. 1978a. Sociedade. In: ADORNO, Theodor W. Temas básicos de sociologia. São Paulo: Cultrix, p. 25-44. 
ADORNO, Theodor W. e HORKHEIMER, Max. 1978b. Indivíduo. In: ADORNO, Theodor. Temas básicos de sociologia. São Paulo: Cultrix. p. 45-6o.

BENJAMIN, Walter. 1994. Experiência e pobreza. In: BENJAMIN, Walter. Obras Escolhidas 1. Magia e Técnica, Arte e Política. São Paulo: Brasiliense. P.114-119.

BRESCIANI, Maria. 1984. Metrópoles: as faces do monstro urbano (as cidades no século. XIX). Revista brasileira de história, São Paulo, v.5, p.35-68.

GIDDENS, Anthony. Modernidade e identidade. Rio de Janeiro: Jorge Zahar, 2002.

HORTON, John. 20o8. Anomia e Alienação: um problema na ideologia da sociologia. In: FORACCHI. M. \& MARTINS. J (Org). Sociologia e Sociedade: Leituras de introdução a sociologia. Rio de Janeiro: LTC, p. 91-106.

LUKÂCS, György. História e consciência de classe: Estudos sobre a dialética marxista. São Paulo: Martins Fontes, 2003.

MARX, Karl. O Capital: crítica da economia política. Rio de Janeiro: Civilização Brasileira, 2016.

MARX, Karl, ENGELS, Friedrich. Ideologia Alemã. Lisboa. Editorial Presença, 1976.

MORAES, Alexandre. 20o6. Sobre a negatividade do conceito de indivíduo em Adorno: a resistência possível. Revista Psicologia USP. São Paulo, vol.17 no.3, p.127-144.

MUSSE, Ricardo. 2016. A administração do tempo livre. Lua Nova, São Paulo, $N^{\circ}$ 99, p. 107-134.

REALE, Giovanni; ANTISERI, Dario. História da filosofia. Vol. VI. São Paulo: Paulinas, 2009. 